\title{
Diasporic Consciousness in the Writings of Rohinton Mistry
}

\author{
Dr. Vijay Negi \\ Assistant Professor, Department of Humanities, DIT University, Dehradun, Uttarakhand, India
}

\begin{abstract}
The nature of the diaspora depends on the nature of the host country. Diasporas, despite their common origin, may behave in a totally different manner depending on the country of their re-location. The narrative of diaspora is essentially a narrative of the 'self'. In the modern context, the word "home" not necessarily connotes as 'self' of belonging and an individual sometimes seems to dwindle between "home" and homeland. For Rushdie, being Indian outside India is a daily questioning of the self. There are also people like Naipaul, who travel because they are not-at-home anywhere. It is also true in case of Rohinton Mistry. Leaving India behind is his own choice for better perspectives in life. At the same time being a Parsi, the historical experience of double displacement imbibed with the author's sense of identification with an alienation from his new and old homelands. The recollection of memories is one of the ways of expression in diasporic writing. The expatriate builds a cocoon around herself/himself as a refuse from 'cultural dilemmas and from the experienced hostility or unfriendliness in the new country'. However, Mistry has overcome the difficulties of human relations between people with different cultural identities. It is his art of balancing the mythical and realistic mode of his writing that helps him in recovering his past in a new land
\end{abstract}

The nature of the diaspora depends on the nature of the host country. Diasporas, despite their common origin, may behave in a totally different manner depending on the country of their re-location. Rohinton Mistry is the best example of presenting different narratives of diaspora while residing in Canada. The narrative of diaspora is essentially a narrative of the 'self'. In the modern context, the word "home" not necessarily connotes as 'self' of belonging and an individual sometimes seems to dwindle between "home" and homeland. For Rushdie, being Indian outside India is a daily questioning of the self. There are also people like Naipaul, who travel because they are not-at-home anywhere. And then what's about the twice removed, those who have taken several roots? For Vassanji's protagonist Ramji in Amriika, home is Africa where his grandmother is and where he grew up, while homeland is India.1 It is also true in case of Mistry. Leaving India behind is his own choice for better perspectives in life. At the same time being a Parsi, the historical experience of double displacement imbibed with the author's sense of 'identification with an alienation from his new and old homelands'.The scattering or movement of people from one nation to another with a common origin, background and beliefs may be termed as 'diaspora'. It is defined as 'the dispersion of the Jews beyond Israel'. It is a Greek origin from 'diaspeirein', 'dia' meaning "across" and 'speirein' meaning "to sow or scatter seeds". The term came into existence during the 3rd century B.C. when the Jews were forced into exile from their homeland to Babylonia. It is referred to those communities who were either displaced or dislocated from their native land through various movements of immigration, migration or exile.

The paper makes a close study of the text of all the three novels and one short story collection of Rohinton Mistry, with a view of describing the element of diasporic consciousness and nostalgia in the wider sense and his efforts and ways of recasting the history of Parsi community as well as the history of the nation. The dimensions of nostalgia are far extended beyond the sentimental longing, to encompass all the meaningexile, displacement, dislocation, relocation, expatriation and assimilation. Simultaneously, some critical views have also been taken into account where Mistry is being attacked for his pro-Canadian stand:

Mistry's winning the Governor-General's medal and other honors in Canadian society for his work on India suggests not just the rewards of writing novels which are critical of homelands, but do not threaten the host country. It also indicates Mistry's effort to say farewell to India and to accelerate his development as a Canadian citizen (Jain 169).

During the study, the scholar came across certain questions regarding the Indian setting of Mistry's writings. Most of the South Asian Canadian writers keep going back to India or the sub-continent for their fictional material. No writer has produced a major book set in Canada and a great Canadian novel that may reflect the Canadian multicultural experience totally is yet to be written. Moving away from Canada and coming closer to India or the homeland makes a writer nostalgic in obvious sense, but some of the critics feel that "his two novels Such a Long Journey and A Fine Balance are elegiac, not nostalgic in tone. They do not celebrate the homeland, but mourn its relentless and innumerable atrocities and tragedies. . they actually enact a farewell to India, not a passage to it"( Jain 167). They feel that Mistry demonstrates a self-legitimating logic of leaving the homeland behind and embracing the new diasporic opportunities. But in-depth study of Mistry's 
writings proves that the dilemma between elegy and nostalgia and between farewell and welcome has given birth to a double-consciousness from the fragments of the past-present. In the process of exploring ones roots a new kind of diasporic narration takes place. Within the structure of the text a new art may emerge from the contradictions of diasporic writers' experiences:

It demands an encounter with "newness" that is not part of the continuum of past and present. It creates a sense of the new as an insurgent act of cultural translation. Such art does not merely recall the part as social cause or aesthetic precedents; it renews the past, refiguring it as a contingent "in between" space, that innovates and interrupts the performance of the present. The "past present" becomes part of the necessity, not the nostalgia, of living (Bhaba 7).

The works of Rohinton Mistry are eminently suitable for this kind of research; not only on account of his unique contribution to the narrative art, but also because, despite a limited quantity of literary production, he has set new yardsticks in diasporic writings. Since the author is Parsi, it seemed essential to go deep into the Zoroastrian roots in order to explore the historical experience of the double displacement of Parsi writer in Canada. Mistry does not believe in quantity rather he focuses on artistic side of literature, thus the study of his contemporaries in South Asian Canadian writing is also taken into account in this chapter. He is claimed to be a postcolonial writer and always tries to demonstrate a medium, which reflects his ideology as well as cultural commitments. What is the mode of writing is a question that has been answered to some extent in this chapter. He shifted to Canada at the age of twenty-three choosing to write in the master's tongue that cannot keep him away from progressive realism. But at the same time putting himself in a contradictory postcolonial complexity, he has chosen to be nostalgic and romance/myth is a genre which best suits to the purpose. The element of diasporic consciousness and nostalgia in this study has dealt with the problem by balancing the glory of myth with more critical mode of reality. The chapter is concluded with a note that Mistry with the help of balancing genre strategy constructed a world where people can achieve harmonious balance between self and society and succeeded to give some meaning to the existence of the Parsi community and its culture.

Mistry's short stories collection Swimming Lessons and Other Stories from Firozsha Baag takes a bird's-eye-view of the narrative techniques of a writer in dealing with the eleven short stories of the collection. It proves Mistry's ability to chart the inner voyage. He attempts to depict the inner lives of all his characters. In this collection he employs new techniques and creative fragmented structures built on impressionistic glimpses of moments. His nostalgia comes on the surface by the remarkable use of stream-of-consciousness technique with flash backs, in a fine blending of time past and time present scheme. The rest of this chapter is devoted to analyze the stories in terms of their theme, setting and structure. The tightening of the structure is very strong in all the stories. The reconstruction of memory is powerfully depicted. To carry over the same character to another story of the collection is also one of the narrative techniques to give it a single binding force and the commonality that links the stories. The presence of one character in more than one story also tightens the structure through Firozsha Baag as the setting of every story. The message of the last story is nostalgic and his world of make believe comes shattering down when on close distance he does not find Canada attractive. The nostalgia reaches at its height and ends the infatuation with the new land where he feels discriminated. The derogatory questions such as, "Are you from India?" "Is swimming not encouraged in India?" shocks him and his move to assimilate. The story ends with a sense of failure:

Failure to swim through filth must mean something other than failure of rebirth-failure of symbolic death? Does that equal success of symbolic life? death of a symbolic failure? Death of a symbol? What is the equation?(240).

The backdrop of the novel Such a Long Journey (1991) deals with the historical movements such as : partition of India and Pakistan, 1962 Indo-China war, falling of Nehruvian dream of a secular India, scam of sixty lakh rupees during Indira Gandhi's rule, and 1971 Indo-Pak war giving birth to Bangladesh. Along with the historical events as its setting and background, the novel is more of inward voyage of the chief characters.Along with the historical events as its setting and background, the novel is more of inward voyage of the chief characters, inhabiting in the Khodadad Building. In this particular novel the writer employs images and symbols more decisively for the reconstruction of his past memories. It is commonly agreed among critics that Such a Long Journey largely deals with the marginalization of the Parsi community, but in this chapter attempts have been made to explore the unifying assimilating factor which presents a complete picture of Parsi community:

The King telling them that you can live either like lemon in milk or like sugar in milk. The Parsis have lived like sugar in milk, speaking the language of the people, eating their food, and yet retaining their identity and living uninterfered with (Kapoor 9).

The novel is unique in the sense that the narrative is made up of a series of reverie. In Mistry's conception of reality, mere description of persons and outward movements is of little significance. Reality is something that exists below the surface: it inhabits the consciousness, and finds expression when the character 
reminisces. Gustad Noble, the chief character becomes nostalgic frequently in the novel and many desires that are unachieved or unfulfilled linger on the border of his consciousness. More often they are expressed through the mythical mode blending with realism.

A Fine Balance consists lot of paradoxical situations, which move the reader to deep pity and even draw tears from one's eyes. However, with the help of an alternate reality the writer seems to make his best efforts to balance the critical life of each of his characters. Mistry confronts, interrogates and challenges the authoritative voice of history. The main symbolic significance of the novel is that life is a struggle in which a courageous individual may win a moral victory against the difficulties and problems of existence. The novel upholds the integrity, dignity, and invincibility of the human mind. The superficial study of the novel makes it difficult to find out nostalgia, but the in-depth reading confirms 'a fine balance' between memory and desire, myth and reality, internal and external reality. The novel, in fact, highlights a crisis of balance where one character is identical with another in his/her struggle and capacity to survive. They retain a collective memory, vision, or myth of their marginalized group - its traumas, sufferings, and struggles and collectively share the efforts of balancing their lives in their different specific ways. The narrative depicts reality of the multi-ethnic groups in the society and their misfortunes and hardships seem exaggeration for those who do not have sensitivity to feel their pain and agony:

Even the criticism of society must be carried out within society. Even planning of society must be carried out within society. Even the description of society must be carried out within society. And all this occurs as the criticism of a society which criticizes itself, as the planning of society which plans itself and always reacts to what happens, and as the description of a society which describes itself (Luhman 17).

In Family Matters, Mistry weaves the lives and memories of one Parsi family into a novel of humanistic dignity, as individuals kick against decay; the decay of flesh into death, the decay of family into death, the decay of surrounding morality, and the decay around and head of us in time. Itis written in a flawless style with a well-knit plot, the novel has all the richness, the compassion, the gentle humour, and the narrative sweep that have earned Rohinton Mistry the highest of accolades and prizes around the world. He is succeeded in maintaining a 'fine balance' between scepticism and affirmation, faith and bigotry, family nurture and control, and once again given something absolutely painfully pleasurable, a bitter sweet rendition of life in its most ordinary intimate setting. The title's obvious double entendre speaks not only of the duties and responsibilities, the matter of a family's workings, but also of how many family matters to us. Family Matters may focus more narrowly than A Fine Balance did, but the grade and truth of Rohinton Mistry's writing still haunts and touches his readers just as profoundly. The portrayal of a man on the cover of the novel, who is looking towards the vastness of the sea, with his back to the reader conveys the feeling of caution, calmness, security, and assimilation. The novel is a memory of moving into the past and the element of nostalgia sharply coming on the surface. It also highlights the sense of belongingness and the crisis of uprootedness. Nariman, aged seventy-nine is divided between two daughters Coomy and Roxana and finds himself in a situation of King Lear, finally, belongs to his family and the family also gradually accepts him. Who does not accept is Coomy and her death shows that Mistry is not at all in a mood of A Fine Balance where everything ends in death and chaos.

In diasporic writing the overwhelming question that thoroughly occurs is - where does one belong? The answer to this question seems to get expression in the previous three works of Mistry, but as time passes it no longer remains important "as to where does one belong but how does one belong"(Birbal Singh 10). Family Matters seems to complete a cycle of belongingness of a diasporic writer who is historically double-displaced. Jasbir Jain finds the similarity between Rohinton Mistry's Family Matters and Neil Bissoondath's Doing the Hard Good:

The protagonists of both the novels have crossed seventy, are widowers and grandfather, deeply appreciative of literature and have to move in with their daughters when they can no longer live by themselves. Both are novels of memory, of moving into the past, both are novels of adjustment with the changed circumstances and finally both are novels of belonging as Nariman (Family Matters)and Alistair Mackenzie (Doing the Heart Good) lean to belong to their families and the families gradually open out their hearts to them. It is not a matter of sheer coincidence that two sensitive writer have turned to a similar concern at the same time. The loneliness, the shift, the process of adjustment and later of acceptance all become a microcosm of the nation as the individual struggles for a place in it (Birbal Singh 10-11).

In a postmodern era a sense of belonging and an act of belongingness find multiple meaning. It is a matter of "becoming" as well as of "being". It belongs as much to the future as to the past. It is not something which already exists in time, history and culture. It is changeable and undergoes constant transformation. In case of diasporic writers it becomes more complicated as "cultural memories, difference of language, of 
attitude, of thinking and histories all interfere" (Birbal Singh 10). The recollection of memories is one of the ways of expression in diasporic writing. The expatriate builds a cocoon around herself/himself as a refuse from 'cultural dilemmas and from the experienced hostility or unfriendliness in the new country'. However, Mistry has overcome the difficulties of human relations between people with different cultural identities. It is his art of balancing the mythical and realistic mode of his writing that helps him in recovering his past in a new land:

Far from being internally fixed in some essentialized past, is subject to the continuous 'play' of history, culture, and power. Far from being grounded in mere "recovery" of the past, which is waiting to be found, and which when found, will secure our sense of ourselves into eternity, identities are the names we give to the different ways we are positioned by, and position ourselves within, the narratives of the past (Hall 23).

\section{Works Cited}

[1]. Bhaba, Homi K. The Location of Culture, London: Routledge. 1994.

[2]. Birbal Singh, Frank "Series Editor's Preface", Jasbir Jain, Neil Bissoondath: Indo-Caribbean-Canadian Diaspora, Jaipur: Rawat Publications. 2005.

[3]. Hall, Stuart "Cultural Identity and Diaspora", Diaspora and Visual Culture, Nicholas Mirzoeff, ed., London: Routledge. 2000.

[4]. Jain,Jasbir "The New Parochialism: Homeland in the Writing of the Indian Diaspora”, In Diaspora, MakarandParanjape, ed., New Delhi:Indialog Publications. 2001.

[5]. Kapoor,Kapil "Keynote Address : Theorizing Diaspora and the Indian Experience", Theorizing and Critiquing Indian Diaspora, Kavita A. Sharma, Adesh Pal and Tapas Chakrabarti, eds., New Delhi : Creative Books. 2004.

[6]. Luhman,Niklas "The Representation of Society Within Society", Political Theory in the Welfare State, trans. John BednarzJr, Berlin : Walter de Gruyter. 1990. 